\title{
АДМІНІСТРАТИВНО-ПРАВОВІ ЗАСОБИ ЗАБЕЗПЕЧЕННЯ ПОЗИТИВНОГО ІНВЕСТИЦІЙНОГО КЛІМАТУ В УКРАЇНІ
}

Одним з основних завдань публічної адміністрації в Україні є покращення інвестиційного клімату з метою залучення максимальної кількості інвестицій у національну економіку, що $€$ умовою іï поступового розвитку та інтеграції в європейський економічний простір. Одним з основних інструментів забезпечення позитивного інвестиційного клімату є система правових засобів, які дають змогу створити систему належних гарантій забезпечення та охорони прав інвесторів, заохочення міжнародних корпорацій до ведення інвестиційної діяльності в Україні. Ключову роль у цьому процесі відіграють саме адміністративно-правові засоби, які створюються та застосовуються суб'єктами владних повноважень органів публічної адміністрації. Публічна адміністрація використовує всі дозволені правові інструменти для забезпечення привабливості національної економіки для інвесторів, тому дослідження правових засобів забезпечення позитивного інвестиційного клімату в Україні має як теоретичне, так $\mathrm{i}$ практичне значення.

Детально дослідили категорію «правові засоби» вітчизняні науковці: О.В. Онуфрієнко у праці «Правові засоби у контексті інструментальної теорії права» [1] та А.М. Денисова в дисертаційному дослідженні на тему «Механізм і засоби правового впливу (теоретико-правове дослідження)» [2].

Категорію «правові засоби» активно використовують у своїх дослідженнях як теоретики права, так і фахівці у сфері адміністративного права: Н.В. Аніщук, В.М. Бевзенко, Т.В. Волинець, Н.В. Волкова, О.О. Ганзенко, Ю.В. Гридасов, І.О. Дзера, Г.В. Єрьоменко, Т.О. Коломоєць, В.К. Колпаков, А.Т. Комзюк, О.В. Кузьменко, М.М. Кузьміна, О.А. Куций, P.С. Мельник, О.С. Мірошниченко, О.О. Небрат, Є.Б. Ольховський, В.В. Пахомов, Д.В. Приймаченко, О.Ю. Салманова, О.О. Степанов, С.Г. Стеценко, Р.Б. Хорольський, А.М. Чернобай та інші відомі науковці.

Серед останніх наукових праць, присвячених дослідженню адміністративно-правових засобів, варто зазначити роботи О.В. Олійника «Адміністративно-правові засоби забезпечення інформаційної безпеки» [3], І.Г. Андрущенко «Адміністративно-правові засоби протидії правопорушенням у сфері злиття і поглинання компаній: питання теорії [4] та М.В. Лошицького "Адміністративно-правові засоби в механізмі охорони навколишнього середовища» [5]. Проте питання адміністративно-правових засобів забезпечення позитивного інвестиційного клімату в Україні досліджено в науковій літературі недостатньо повно, що актуалізує проведення цього дослідження.

Метою наукової публікації є дослідження поняття адміністративно-правових засобів забезпечення позитивного інвестиційного клімату в Україні, їх класифікація та формулювання пропозицій щодо напрямів їх удосконалення.

Поняття правових засобів доволі змістовно досліджувалось фахівцями з теорії держави та права. Так, на думку О.В. Онуфрієнко, правові засоби - це система субстанціональних та діяльнісних правових явищ, за допомогою яких конкретні суб'єкти правовідносин досягають приватних та публічних цілей [1, с. 14-15].

$€$ думка, що правові засоби - це певні юридичні категорії та діяння суб'єктів з їх застосування з метою досягнення конкретного результату $[6$, c. 536$]$.

В юридичній літературі правові засоби класифікують за різними критеріями. Залежно від ступеня складності розрізняють: прості (суб'єктивні права та юридичні обов'язки; заохочення i покарання; пільги та заборони); складні (норма; інститут). Залежно від функціонального призначення виділяють регулятивні (дозволи) та охоронні (засоби захисту). За предметом правового регулювання - конституційні, адміністративні, цивільні, кримінальні тощо. За характером - матеріальні (рекомендації); процесуальні (позов). За часом дії - постійні (громадянство), тимчасові (премія). Залежно від виду правового регулювання - нормативні (заборони, встановлені нормами права), індивідуальні (акт застосування права). Залежно від інформаційно-психологічної спрямованості - стимулюючі (заохочення), обмежуючі (примус) [6, с. 536-537].

А.М. Денисова формулює авторське визначення поняття "правові способи», під якими розуміє правові явища, які відображені в інструментах (постановах) та діях (технологіях), за допомогою яких задовольняються інтереси суб'єктів права, забезпечується досягнення особистих та публічних цілей. Загальні ознаки правових засобів, на 
її думку, полягають у тому, що вони: є основними інструментами суб'єктів права для забезпечення особистих та публічних інтересів, досягнення поставлених цілей; відображають соціальну, інструментальну та особистісну цінності права; визначають, певним чином поєднуючись, галузеві правові режими; є основними елементами правового впливу, механізму правового регулювання; є спеціальними та загальними засобами, які забезпечують дію правової системи загалом; призводять до юридичних наслідків (конкретних результатів); забезпечують ефективність правового регулювання завдяки постійному взаємозв'язку один з одним; забезпечуються та підтримуються державою [7, с. 190-191].

До субстанціональних правових засобів (засобів-постанов, інструментів) А.М. Денисова зараховує зобов' язання, дозволи, заборони, заохочення, пільги, норми права, принципи права тощо, в той час як до дієвих (засобів-дій, технологій) - акти реалізації права, акти застосування права, акти тлумачення права і всі процеси юридичної діяльності. Всі правові засоби, на її думку, в результаті узагальнення (трансформації), поділяються на правові стимули та правові обмеження. Правовий стимул визначається як засіб формування в суб' $є$ та необхідної законослухняної поведінки шляхом створення необхідних умов щодо задоволення суб'єктивних інтересів суб'єкта завдяки виконанню правових приписів. А правові обмеження - це правовий засіб стримування протиправного діяння, що створює умови для задоволення інтересів уповноваженого суб'єкта і суспільних інтересів в охороні й захисті [7, с. 191-192].

Адміністративно-правові засоби як різновид правових засобів вирізняються тим, що створюються та застосовуються суб'єктами владних повноважень органів публічної адміністрації 3 метою регулювання публічних (адміністративно-правових) відносин. Адміністративно-правові засоби використовуються громадянами та юридичними особами у відносинах з органами публічної адміністрації з метою реалізації та захисту своїх прав і свобод.

3 огляду на вищезазначене до адміністративно-правових засобів забезпечення позитивного інвестиційного клімату в Україні доцільно зарахувати:

- норми Конституції України, які гарантують недоторканість приватної власності та особи, презумпцію невинуватості, свободу підприємницької діяльності, закріплюють євроінтеграційний курс України, тобто ті елементи правової системи, які гарантують безпеку потенційному інвестору та забезпечують захищеність інвестицій;

- міжнародні договори, ратифіковані Верховною Радою України, серед яких провідне місце посідає Угода про асоціацію між Україною та ЄС
(Угоду ратифіковано із заявою Законом України № 1678-VII від 16.09.2014 р.) [8];

- відповідне національне законодавство: чинні закони України щодо розвитку, стимулювання, забезпечення та захисту інвестиційної діяльності, відповідні укази Президента та постанови Кабінету Міністрів України;

- відомчі нормативно-правові акти міністерств та інших органів публічної адміністрації, які деталізують законодавчі акти щодо порядку та засобів здійснення інвестиційної діяльності;

- акти судової гілки влади, серед яких провідне місце займають Рішення Конституційного Суду України, Висновки (правові позиції) Верховного Суду, в яких визначаються уніфіковані підходи, правила щодо застосування норм матеріального та процесуального права у сфері інвестицій та інвестиційної діяльності;

- типові інвестиційні угоди та супровідні документи, які є результатом усталеної юридичної практики у сфері інвестиційної діяльності;

- методичні рекомендації доктринального рівня щодо порядку та засобів здійснення інвестиційної діяльності, які є результатом наукового узагальнення економічних процесів, статистичної інформації, чинного та перспективного законодавства, а також прогнозування розвитку світового та національного ринків;

- індивідуальні економіко-юридичні консультації фахівців у сфері інвестиційної діяльності щодо пріоритетних напрямів та способів здійснення інвестиційної діяльності у певній державі або їі окремих регіонах;

- інформаційні ресурси мережі Інтернет економічного та юридичного характеру, які містять інформацію про об'єкти інвестиційної діяльності, інформацію про установи, підприємства та організації, яка є необхідною для оцінки інвестиційних ризиків та потенційного прибутку тощо (інформація щодо засновників, статутного капіталу, податкові та кредитні зобов'язання, пов'язаних контрагентів, основні види діяльності, факти притягнення до юридичної відповідальності, внесення змін до статутних документів тощо).

Серед законів, які виступають правовою основою здійснення інвестиційної діяльності та забезпечення позитивного інвестиційного клімату в Україні, варто визначити закони України: «Про інвестиційну діяльність», «Про режим іноземного інвестування», «Про стимулювання інвестиційної діяльності у пріоритетних галузях економіки 3 метою створення нових робочих місць». Серед останніх - Закон України «Про внесення змін до деяких законодавчих актів України щодо стимулювання інвестиційної діяльності в Україні» від 20 вересня 2019 р. № 132-IX.

Так, Закон України «Про інвестиційну діяльність» від 18 вересня 1991 р. визначає загальні 
правові, економічні та соціальні умови інвестиційної діяльності на території України. Він спрямований на забезпечення рівного захисту прав, інтересів і майна суб'єктів інвестиційної діяльності незалежно від форм власності, а також на ефективне інвестування економіки України, розвитку міжнародного економічного співробітництва та інтеграції [9].

Відповідно до ст. 1 Закону України «Про інвестиційну діяльність» інвестиціями є всі види майнових та інтелектуальних цінностей, що вкладаються в об'єкти підприємницької та інших видів діяльності, в результаті якої створюється прибуток (доход) та/або досягається соціальний та екологічний ефект. Такими цінностями можуть бути: кошти, цільові банківські вклади, паї, акції та інші цінні папери (крім векселів); рухоме та нерухоме майно (будинки, споруди, устаткування та інші матеріальні цінності); майнові права інтелектуальної власності; сукупність технічних, технологічних, комерційних та інших знань, оформлених у вигляді технічної документації, навичок та виробничого досвіду, необхідних для організації того чи іншого виду виробництва, але не запатентованих («ноу-хау»); права користування землею, водою, ресурсами, будинками, спорудами, обладнанням, а також інші майнові права; інші цінності. Інвестиції, що спрямовуються на створення (придбання), реконструкцію, технічне переоснащення основних засобів, очікуваний строк корисної експлуатації яких перевищує один рік, здійснюються у формі капітальних вкладень.

Згідно із ст. 2 Закону України «Про інвестиційну діяльність», інвестиційною діяльністю є сукупність практичних дій громадян, юридичних осіб і держави щодо реалізації інвестицій. Інвестиційна діяльність провадиться на основі: інвестування, що здійснюється громадянами, недержавними підприємствами, господарськими асоціаціями, спілками і товариствами, а також громадськими і релігійними організаціями, іншими юридичними особами, заснованими на колективній власності; державного інвестування, що здійснюється органами державної влади за рахунок коштів державного бюджету, позичкових коштів, а також державними підприємствами та установами за рахунок власних і позичкових коштів; місцевого інвестування, що здійснюється органами місцевого самоврядування за рахунок коштів місцевих бюджетів, позичкових коштів, а також комунальними підприємствами та установами за рахунок власних і позичкових коштів; державної підтримки для реалізації інвестиційних проектів; іноземного інвестування, що здійснюеться іноземними державами, юридичними особами та громадянами іноземних держав; спільного інвестування, що здійснюється юридичними особами та громадянами України, юридичними особами та громадя- нами іноземних держав. Інвестиційна діяльність забезпечується шляхом реалізації інвестиційних проектів і проведення операцій із корпоративними правами та іншими видами майнових та інтелектуальних цінностей [9].

Закон України «Про режим іноземного інвестування» від 19 березня 1996 р. № 93/96-ВР визначає особливості режиму іноземного інвестування на території України, з огляду на цілі, принципи і положення законодавства України. Так, відповідно до ст. 2 вказаного закону іноземні інвестиції можуть здійснюватися у вигляді: іноземної валюти, що визнається конвертованою Національним банком України; валюти України - відповідно до законодавства України; будь-якого рухомого i нерухомого майна та пов'язаних із ним майнових прав; акцій, облігацій, інших цінних паперів, а також корпоративних прав (прав власності на частку (пай) у статутному капіталі юридичної особи, створеної відповідно до законодавства України або законодавства інших країн), виражених у конвертованій валюті; грошових вимог та права на вимоги виконання договірних зобов'язань, які гарантовані першокласними банками і мають вартість у конвертованій валюті, підтверджену згідно з законами (процедурами) країни інвестора або міжнародними торговельними звичаями; будь-яких прав інтелектуальної власності, вартість яких у конвертованій валюті підтверджена згідно з законами (процедурами) країни інвестора або міжнародними торговельними звичаями, а також підтверджена експертною оцінкою в Україні, включаючи легалізовані на території України авторські права, права на винаходи, корисні моделі, промислові зразки, знаки для товарів і послуг, ноухау тощо; прав на здійснення господарської діяльності, включаючи права на користування надрами та використання природних ресурсів, наданих відповідно до законодавства або договорів, вартість яких у конвертованій валюті підтверджена згідно 3 законами (процедурами) країни інвестора або міжнародними торговельними звичаями; інших цінностей відповідно до законодавства України.

Згідно із ст. 3 Закону України «Про режим іноземного інвестування» іноземні інвестиції можуть здійснюватися в таких формах: часткової участі у підприємствах, що створюються спільно з українськими юридичними і фізичними особами, або придбання частки діючих підприємств; створення підприємств, що повністю належать іноземним інвесторам, філій та інших відокремлених підрозділів іноземних юридичних осіб або придбання у власність діючих підприємств повністю; придбання не забороненого законами України нерухомого чи рухомого майна, включаючи будинки, квартири, приміщення, обладнання, транспортні засоби та інші об'єкти власності, шляхом прямого одержання майна та майнових комплексів або 
у вигляді акцій, облігацій та інших цінних паперів; придбання самостійно чи за участю українських юридичних або фізичних осіб прав на користування землею та використання природних ресурсів на території України; придбання інших майнових прав; господарської (підприємницької) діяльності на основі угод про розподіл продукції; в інших формах, які не заборонені законами України, в тому числі без створення юридичної особи на підставі договорів із суб'єктами господарської діяльності України [10].

Іноземні інвестиції можуть вкладатися в будьякі об'єкти, інвестування в які не заборонено законами України.

Закон України «Про стимулювання інвестиційної діяльності у пріоритетних галузях економіки з метою створення нових робочих місць» від 6 вересня 2012 р. № 5205-VI визначає основи державної політики в інвестиційній сфері протягом 2013-2032 pр. щодо стимулювання залучення інвестицій у пріоритетні галузі економіки. Цей закон спрямований на створення умов для активізації інвестиційної діяльності шляхом концентрації ресурсів держави на пріоритетних напрямах розвитку економіки з метою запровадження новітніх та енергозберігаючих технологій, створення нових робочих місць, розвитку регіонів [11].

Новелою національного законодавства у сфері забезпечення позитивного інвестиційного клімату є Закон України «Про внесення змін до деяких законодавчих актів України щодо стимулювання інвестиційної діяльності в Україні» від 20 вересня 2019 р. № 132-IX [12].

У пояснювальній записці до проекту Закону України «Про внесення змін до деяких законодавчих актів України щодо стимулювання інвестиційної діяльності в Україні» в обгрунтування необхідності прийняття акта зазначається, що протягом останніх років Україна демонструвала поступове зростання в міжнародному рейтингу Doing Business, однак наше місце в ньому все одно залишається досить низьким, в тому числі порівняно з окремими країнами пострадянського простору. У багатьох аспектах Україна має недосконале правове регулювання, що має наслідком несприятливий бізнес-клімат та відсутність реальних стимулів до здійснення активної інвестиційної діяльності.

Щодо сфери захисту прав акціонерів окремо зазначається, що українське законодавство недостатньою мірою забезпечує захист прав та інтересів міноритарних інвесторів. У нашій правовій системі відсутні положення про відповідальність осіб із заінтересованістю та посадових осіб акціонерного товариства за збитки, завдані правочином із заінтересованістю, згода на вчинення якого була надана мажоритарним акціонером або призначеними ним особами. Крім того, перелік пра- вочинів, які вважаються правочинами із заінтересованістю, не покриває достатнього кола відносин акціонерного товариства з його пов'язаними контрагентами.

Крім того, зазначається, що однією з головних проблем економіки України є недоступність для вітчизняного бізнесу кредитних коштів, що є закономірним наслідком надмірно високих кредитних ставок. Своєю чергою, дорогі кредитні кошти пояснюються не тільки значним рівнем інфляції, але й високими ризиками неповернення (несвоєчасного повернення) боржниками отриманих ними кредитів. При цьому наявні механізми забезпечення виконання зобов'язань $є$ досить застарілими. Вони не працюють неналежним чином і не дають змоги забезпечити ефективний захист прав кредиторів. Пов'язані з примусовим стягненням заборгованості судові спори та примусове виконання судових рішень тривають роками і далеко не завжди кредиторам вдається стягнути заборгованість навіть із платоспроможних позичальників.

Зрештою, вітчизняні підприємства практично відрізані від кредитних ресурсів банківської системи. При цьому реформування традиційних механізмів забезпечення зобов'язань (зокрема застави) є непростим з огляду на кількість уже укладених договорів застави (іпотеки). Будь-які істотні зміни у відповідному регулюванні порушать баланс інтересів кредиторів та позичальників, уже досягнутий за допомогою договірних інструментів. Тому доцільним є запровадження абсолютно нового інструменту забезпечення виконання кредитних зобов'язань, який би зменшував до обгрунтованого мінімуму ризики кредиторів, пов'язані з поверненням проблемної заборгованості, та створював передумови для зростання обсягів кредитування бізнесу [13].

Підсумовуючи, варто зазначити, що Закон України «Про внесення змін до деяких законодавчих актів України щодо стимулювання інвестиційної діяльності в Україні» від 20 вересня 2019 р. № 132-IX є доволі складним для сприйняття і демонструє значну кількість нормативно-правових актів, які регулюють окремі аспекти інвестицій та інвестиційної діяльності. Враховуючи вищезазначене, $є$ нагальна потреба у проведенні систематизації нормативно-правових актів у сфері інвестиційної діяльності, створенні єдиного документа, який буде зручним у користуванні, зрозумілим для потенційного інвестора, що, відповідно, буде сприяти покращенню інвестиційного клімату загалом.

Дослідження категорії «правові засоби» дало змогу сформулювати висновок, що адміністративно-правові засоби як різновид правових засобів вирізняються тим, що створюються та застосовуються суб'єктами владних повноважень органів публічної адміністрації з метою регулювання публічних (адміністративно-правових) відносин. 
Адміністративно-правові засоби використовуються громадянами та юридичними особами у відносинах з органами публічної адміністрації з метою реалізації та захисту свої прав і свобод.

3 огляду на вищезазначене, до адміністративно-правових засобів забезпечення позитивного інвестиційного клімату в Україні доцільно зарахувати: норми Конституції України; міжнародні договори, ратифіковані Верховною Радою України, серед яких провідне місце посідає Угода про асоціацію між Україною та ЄС; відповідне національне законодавство (чинні закони України щодо розвитку, стимулювання, забезпечення та захисту інвестиційної діяльності, відповідні Укази Президента та Постанови Кабінету Міністрів України); відомчі нормативно-правові акти міністерств та інших органів публічної адміністрації, які деталізують законодавчі акти щодо порядку та засобів здійснення інвестиційної діяльності; акти судової гілки влади, серед яких провідне місце займають Рішення Конституційного Суду України, Висновки (правові позиції) Верховного Суду, в яких визначаються уніфіковані підходи, правила щодо застосування норм матеріального та процесуального права у сфері інвестицій та інвестиційної діяльності; типові інвестиційні договори та супровідні документи, які є результатом усталеної юридичної практики у сфері інвестиційної діяльності; методичні рекомендації доктринального рівня щодо порядку та засобів здійснення інвестиційної діяльності, які є результатом наукового узагальнення економічних процесів, статистичної інформації, чинного та перспективного законодавства, а також прогнозування розвитку світового та національного ринків; індивідуальні економіко-юридичні консультації фахівців у сфері інвестиційної діяльності щодо пріоритетних напрямів та способів здійснення інвестиційної діяльності у певній державі або їі окремих регіонах; інформаційні ресурси мережі Iнтернет економічного та юридичного характеру, які містять інформацію про об'єкти інвестиційної діяльності, інформацію про установи, підприємства та організації, яка є необхідною для оцінки інвестиційних ризиків та потенційного прибутку тощо.

3 метою удосконалення системи адміністративно-правових засобів забезпечення позитивного інвестиційного клімату в Україні доцільним вбачається проведення систематизації нормативно-правового матеріалу у сфері інвестицій та інвестиційної діяльності у формі консолідації та створення єдиного нормативно-правового акта, який буде регулювати основні питання інвестиційної діяльності, засобів її стимулювання та розвитку, містити типові види інвестиційних угод. Необхідність наукового обгрунтування та розробки концепції такого комплексного нормативно-правового акта зумовлює перспективність подальшого дослідження цієї тематики.

\section{Jimepamypa}

1. Онуфрієнко О.В. Правові засоби у контексті інструментальної теорії права : автореф. дис... канд. юрид. наук : 12.00.01 «Теорія та історія держави і права; історія політичних і правових учень» / Національний ун-т внутрішніх справ. Харків, 2004. 18 с.

2. Денисова А.М. Механізм і засоби правового впливу (теоретико-правове дослідження) : дис... канд. юрид. наук : 12.00.01 «Теорія та історія держави і права; історія політичних і правових учень» / Національна академія внутрішніх справ МВС України. Київ, 2012. 230 с.

3. Олійник О.В. Адміністративно-правові засоби забезпечення інформаційної безпеки. Юридичний вісник. 2015. № 1 (34). С. 6569 .

4. Андрущенко І.Г. Адміністративно-правові засоби протидії правопорушенням у сфері злиття і поглинання компаній: питання теоріі. Право і суспільство. 2014. № 6-2. С. 3944.

5. Лошицький М.В. Адміністративно-правові засоби в механізмі охорони навколишнього середовища. Митна справа. 2015. № 1 (97). С. 7985.

6. Теорія держави і права. Академічний курс : підручник / О.В. Зайчук (відп. ред.), А.П. Заєць, В.С. Журавський, О.Л. Копиленко, Н.М. Оніщенко. Київ : Юрінком Інтер, 2006. 685 с.

7. Денисова А. Правові засоби: поняття та види. Право України. 2010. № 7. С. 190195.

8. Угода про асоціацію між Україною, з однієї сторони, та Європейським Союзом, Європейським співтовариством 3 атомної енергії ї їніми державами-членами, з іншої сторони. Дата оновлення: 30.11 .2015 р.

URL: http://zakon3.rada.gov.ua/laws/show/984_011.

9. Про інвестиційну діяльність : Закон України від 18 вересня 1991 р. № 1560-XII. Дата оновленн.я: 18.12.2017 p. URL: https://zakon.rada.gov.ua/laws/ show $/ 1560-12$

10. Про режим іноземного інвестування : Закон України від 19 березня 1996 р. № 93/96-ВР. Дата оновлення: 25.06.2016 p. URL: https://zakon.rada.gov.ua/ laws/show/93/96-вр.

11. Про стимулювання інвестиційної діяльності у пріоритетних галузях економіки з метою створення нових робочих місць : Закон України від 6 вересня 2012 р. № 5205-VI. Дата оновлення: 01.01.2013 p. URL: https://zakon.rada.gov.ua/laws/show/5205-17.

12. Про внесення змін до деяких законодавчих актів України щодо стимулювання інвестиційної діяльності в Україні : Закон України від 20 вересня 2019 p. № 132-IX. Дата оновлення: 17.10.2019 p. URL: https://zakon.rada.gov.ua/laws/show/132-20.

13. Пояснювальна записка до проекту Закону України «Про внесення змін до деяких законодавчих актів України щодо стимулювання інвестиційної діяльності в Україні" / Верховна Рада України: офіційний веб-портал. URL: https://w1.c1.rada.gov.ua/pls/ zweb2/webproc4_1?pf3511=66289. 


\section{Анотація}

Разіна Т. I. Адміністративно-правові засоби забезпечення позитивного інвестиційного клімату в Українi. - Стаття.

У науковій публікації досліджуються поняття та види адміністративно-правових засобів забезпечення позитивного інвестиційного клімату в Україні. Зазначається, що адміністративно-правові засоби як різновид правових засобів вирізняються тим, що створюються та застосовуються суб'єктами владних повноважень органів публічної адміністрації з метою регулювання публічних (адміністративно-правових) відносин. Адміністративно-правові засоби використовуються громадянами та юридичними особами у відносинах з органами публічної адміністрації з метою реалізації та захисту свої прав і свобод.

До адміністративно-правових засобів забезпечення позитивного інвестиційного клімату в Україні зараховано: норми Конституції України; міжнародні договори, ратифіковані Верховною Радою України, серед яких провідне місце посідає Угода про асоціацію між Україною та ЄС; відповідне національне законодавство; відомчі нормативно-правові акти міністерств та інших органів публічної адміністрації; акти судової гілки влади, серед яких провідне місце займають Рішення Конституційного Суду України, Висновки (правові позиції) Верховного Суду; типові інвестиційні договори та супровідні документи, які є результатом усталеноі юридичної практики у сфері інвестиційної діяльності; методичні рекомендації доктринального рівня щодо порядку та засобів здійснення інвестиційної діяльності; індивідуальні економіко-юридичні консультаціі фахівців у сфері інвестиційної діяльності; інформаційні ресурси мережі Інтернет економічного та юридичного характеру, які містять інформацію про об'єкти інвестиційної діяльності.

Формулюється висновок, що з метою удосконалення системи адміністративно-правових засобів забезпечення позитивного інвестиційного клімату в Україні доцільним вбачається проведення систематизації нормативно-правового матеріалу у сфері інвестицій та інвестиційної діяльності у формі консолідації та створення єдиного нормативно-правового акта, який буде регулювати основні питання інвестиційної діяльності, засобів їі стимулювання та розвитку, містити типові види інвестиційних угод.

Ключові слова: правові засоби, адміністративно-правові засоби, інвестиції, інвестиційна діяльність, інвестиційний клімат, законодавство, публічна адміністрація, систематизація, консолідація, удосконалення.

\section{Summary}

Razina T. I. Administrative and legal means of ensuring a positive investment climate in Ukraine. Article.

In the scientific publication the concepts and types of administrative and legal means of ensuring a positive investment climate in Ukraine are analyzed. It is noted that administrative means as a type of legal means are distinguished by the fact that they are created and used by the bodies of public authority of public administration for the purpose of regulating public (administrative-legal) relations. Administrative means are used by citizens and legal entities in relations with public administration bodies in order to exercise and protect their rights and freedoms.

The administrative and legal means of ensuring a positive investment climate in Ukraine include: the norms of the Constitution of Ukraine; international agreements, among which the Association Agreement between Ukraine and the EU holds the leading position; relevant national legislation; departmental regulatory acts of ministries and other bodies of public administration; acts of the judicial branch of power, among which the leading place is taken by the Constitutional Court of Ukraine, Conclusions (legal positions) of the Supreme Court; standard investment contracts and accompanying documents that result from established legal practice in the field of investment activity; methodological recommendations of the doctrinal level on the procedure and means of investment activities; individual economic and legal consultations of experts in the sphere of investment activity; information resources of the Internet of economic and legal nature that contain information about the objects of investment activity.

It is stated that in order to improve the system of administrative and legal means of ensuring a positive investment climate in Ukraine, it is advisable to carry out the systematization of regulatory material in the field of investment and investment activities in the form of consolidation and to create a single regulatory act that will regulate the issues investment activities, means of stimulating and developing them, contain typical types of investment agreements.

Key words: legal means, administrative means, investments, investment activity, investment climate, legislation, public administration, systematization, consolidation, improvement. 